\title{
Europe and the World of Learning: Orthodoxy and Aspiration in the Wake of Modernity
}

\section{PÁDRAIG HOGAN}

\begin{abstract}
If Rome was for centuries the centre of power and influence for Christendom and the European world of learning associated with it, Brussels can claim to be such a twofold centre in the late twentieth century. The radical pluralism and postmodernist orientations which are now part of the Enlightenment legacy becloud the point that a new uniformity of belief and outlook - mercenary rather than spiritual furnishes the context for most educational policy-making in European countries. Far from calling for a return to a patriarchal past, the paper attempts to sketch an understanding of education as a universally defensible practice, while addressing the challenges of both postmodernism and the new uniformity.
\end{abstract}

\section{CONTROL AND SERVITUDE IN A NEW KEY}

Until quite recently the predominant conceptions of education in the western world were informed by ideals of Greek and Roman ancestry and also by ones with origins in European Christendom. Despite the rise of pluralism, which has been one of the main cultural legacies of the Enlightenment over the last two centuries, classical and religious influences remained central to education in most Western countries until the later decades of the twentieth century. A few examples will serve to illustrate this and also to highlight the extent to which times have changed in the last few decades.

Henri Marrou's noted work, A History of Education in Antiquity, was published in 1956 and in the Introduction to that book Marrou wrote: 'We are the heirs of the Graeco-Latins, and everything of importance in our own civilisation derives from theirs. Most of all this is true of our system of education' (Marrou, 1956, pp. xi-xii). The confident authority evident in Marrou's words suggests that centuries of continuity had bequeathed an order of things that was definitive of western learning and civilisation: an order that had largely withstood the upheavals of history and would endure into the future. Education at the Crossroads, by Marrou's fellow Frenchman Jacques Maritain, first appeared in 1943 
in the United States and was re-issued in a succession of printings during the 1960s. In this work Maritain strongly championed a classicalChristian conception of education, but also voiced anxieties about its future. Identifying the sources of these anxieties to include the rise of a 'purely scientific idea of man', the growth of pragmatist outlooks in American democracy and the successes of Nazi Germany in the (then unfinished) Second World War, Maritain called for a major renewal of educational energies inspired by spiritual ideals.

But to maintain the kind of continuity described by Marrou, or to promote the kind of renewal advocated by Maritain, would require on the part of the state a recognition of purposes which were integral to education as a realm apart from those of politics and commerce: indeed a readiness on the state's part to protect these purposes from the designs of different interest groups, including politicians. Secondly, it would require schooling to be insulated in some effective degree by school authorities and teachers from prominent influences in the everyday world: for instance, those influences in cultural and economic life which Maritain's arguments identified as injurious to the western classical and religious heritage in education. But in the educational reforms of the late twentieth century the intrusion of political purposes into schooling has intensified rather than waned in most western democracies. In addition, the capacity of the churches to insulate their schools from unwelcome influences has declined dramatically. A major depletion in the ranks of religious life and the ubiquity of the modern international entertainment industry are just two among many reasons for this latter development. But it is the first, the strategic involvement of the state in the field of education, which will concern us more directly here.

From the revolutionary aftermath of the Enlightenment onwards, the declining influence of classical and religious ideals in education was accompanied by a progressive rise of influences of a more disparate character. Notwithstanding the appeals to traditional ideals of western learning by writers like Marrou and Maritain, centrifugal cultural forces continued apace, in educational circles as elsewhere. Prominent among these in the later 1960s and 1970s were ideals associated with social democratic aspirations for equality of educational opportunity. Even more prominent in our own day are influences associated with the imperatives of economic growth, technological progress, and the 'market place' ${ }^{1}{ }^{\text {A recent }}$ 'White Paper on Education and Training' issued by the Commission of the European Communities, Teaching and Learning: Towards the Learning Society (European Commission 1996), is an international landmark in this respect. The White Paper embraces economic and technological influences in a bold sense and reveals - albeit unwittingly - that the dominant authority exercised by the church in education in the era of European Christendom is now being largely claimed by new hands and is being largely exercised on behalf of a new faith.

From a critical point of view, a number of important observations can be made about this turn of events, but here I shall confine myself to two. In the first place, the independence from temporal authorities enjoyed by 
the Christian church(es) in the field of education in earlier centuries had its theological foundations in the notion of the church's libertas, the freedom to preach the word of God. But, far from unequivocally marking an enterprise with its own intellectual freedom, this libertas was subject to the enforceable requirements of doctrinal orthodoxy (later a denominational orthodoxy), both in regard to what could be taught and what could be questioned. On this authoritarian aspect of church involvement in education, works like Maritain's are largely silent. Secondly, most Enlightenment thinkers viewed themselves as emancipating thought and belief from the prejudices engendered by centuries of obedience to authority and tradition. Yet this emancipation yielded little as far as the conduct of teaching and learning was concerned.

Notwithstanding the efforts of Rousseau and later figures like Pestalozzi and Froebel to displace inherited ideas about the practices of teaching and learning, the first educational legacy of the Enlightenment was to unleash struggles between old and newly aspirant groups for control of the enterprise of education. Such struggles left the traditional conduct of practices of teaching and learning largely unreformed. That is to say, new controlling authorities sought to furnish the enterprise with new aims but they continued to view teachers mainly as servile instruments of the controlling authorities themselves. ${ }^{2}$

On this account of things, the current enshrining of a competitive ethic in a seminal document for educational policy in the European Union has an historical importance which can easily be overlooked. The adoption of Teaching and Learning: Towards the Learning Society as a European policy document marks the emergence of something like an ultimate victor, at least for the time being, from the struggles of competing interests for control of the tenor of educational policy over the last two centuries. In a manner reminiscent of a recent book whose title proclaimed the end of history (Fukuyama 1992), this 1996 White Paper boldly announces that debates over the aims of education are now at an end, ${ }^{3}$ and proceeds from the outset on the assumption that the distinction between education and training is obsolete. It goes on to declare five 'general objectives' for building 'the learning society', passing over the point that some of these are not only debatable but quite problematic as educational goals: (i) skilling pupils in the new knowledge which is needed by advanced technological societies if their continued economic growth is to be assured; (ii) bringing schools and business closer together; (iii) combating social exclusion; (iv) promoting proficiency in three (European) community languages; (v) treating capital investment and investment in training on an equal basis. ${ }^{4}$

One could readily make the argument at this point that the conception of education being advanced here springs from a newly sophisticated utilitarianism and that it signals a new kind of servitude for teachers and learners, different in nature but no less inclusive in its scope than that of the medieval world of Christendom. And this twofold charge cannot easily be refuted. But the argument needs to be more incisive than this to capture the real significance of the altered circumstances in which 
education as a public engagement is now being placed. Where the traditional penalties for going one's own way in the face of the decreed orthodoxies of Christendom included terror and sometimes torture, the orthodoxies of the present are more subtle, but for that matter also more persuasive. Reluctance to make concessions in one's practice to the newly declared imperatives of European policy-makers carries an increasing likelihood of having one's practice frugally resourced, or else marginalised. Willingness or deftness in aligning one's attitudes and educational efforts, on the other hand, is likely to be rewarded by the availability of grants or other inducements for participation in a variety of actively promoted European initiatives and programmes.

These remarks seem to suggest that education as a public concern in modern western civilisation has lost sight of its cultural heart; that it has even entered a new Dark Age. And this is a conclusion which appears frequently in one form or another in the educational debates and critiques of our day. ${ }^{5}$ But it may be objected at this point that the picture I have just drawn in broad strokes is far too general: that it neglects important points of detail and that it fails to do justice to tendencies of a contrary kind to the ones I have highlighted. It is important then to look at this picture more closely and to understand that it actually represents an unsurprising outcome of an era of pluralism, but a pluralism marked as much by intractable acrimonies as by new forms of mutual toleration and accommodation. The most important purpose of examining this picture, however, goes beyond the purposes of critique. It is to bring to light a promising understanding of educational practice which supplies coherent and defensible grounds for its own claims to integrity: an active understanding which embodies a dynamic interplay of learner and tradition, which neglects neither the challenges nor opportunities of technological society, but which also seeks to do justice to the issues of self-understanding and personal identity in contexts of unprecedented cultural diversity.

\section{CONSEQUENCES OF WILD PLURALISM}

The late eighteenth century marks the high point of the Enlightenment. The two centuries which have elapsed since then have witnessed successive stages in the struggles of pluralism to supersede the uniformities and dominances of the pre-modern age and to become a central virtue of civic life in the democracies which are heir to Enlightenment ideals. Despite the many successes which have been wrought by pluralist efforts from the upheavals of these two centuries, and despite the fact that pluralist principles are now enshrined in many state constitutions and enacted in countless pieces of legislation, it is doubtful if pluralism as a civic virtue is cherished and actively practised by anything more than a minority of citizens in any of the western democracies. ${ }^{6}$ This is particularly evident in the educational debates and controversies of recent years, where the jockeying for advantage by competing interest groups is scarcely less vigorous than it was in the mid-nineteenth century. 
The transition from a pre-modern society to a pluralist one is marked by the emergence of significant rival voices and by the ascent of some of these voices to a position of near comparable influence, or comparable recognition, to the previously dominant tradition. And in its most mature form, pluralism as a virtue of civic life promotes ordered debates between contrasting traditions, encourages mutual respect and understanding between them and makes provision for reciprocal accommodations within publicly recognised frameworks which recognise the most important human rights as being universal. In this sense pluralism is a practical expression of democratic convictions, and it identifies one of the chief civic aspirations of modernity in western civilisations, from the Enlightenment to the later twentieth century. But in the absence of an abiding commitment to such aspirations, pluralism is likely to go 'wild', even within countries governed by democratic constitutions. Richard J. Bernstein has described 'wild pluralism' as 'a pluralism in which we are so enclosed in our own frameworks and our own points of view that we seem to be losing the civility, desire, and even the ability to communicate and share with others' (Bernstein, 1987, p. 522). This describes a situation where critique of other standpoints becomes chiefly a selfserving preoccupation, and where the more demanding issue of selfcritique and the more practical question 'critique in the name of what?' receive comparatively little attention.

Bernstein argues that 'wild pluralism' in the United States 'has infected almost every aspect of our everyday lives and has spread to virtually every area of human culture' (Bernstein, 1987, p. 522). Alasdair MacIntyre also highlights this acrimonious kind of pluralism, describing it as 'an unharmonious melange of ill-assorted fragments' (MacIntyre, 1981, p. 10) and voices his suspicion - and later on his considered viewpoint - that this is the kind of pluralism that has become predominant in those societies where the Enlightenment legacy has had the strongest effects. Whether or not one agrees with Bernstein on the extent of wild pluralism, or with MacIntyre on the baleful consequences of the Enlightenment, one should not overlook the fact that attention is being drawn to an important issue here. Wild pluralism is the outcome of a failure, over a few generations, to meet successfully a range of challenges and moral demands - those which arise when different traditions are thrown together in a given state or society, or, more particularly, those which arise when a previously dominant tradition has its dominance undermined by traditions which are resistant or antagonistic to some of its key features.

This suggests that, in major respects, the rationalist aspirations of high modernity are overtaken by educational purposes which no longer find - or even seek - foundations in arguments that are to apply to humankind as a whole. But I also wish to suggest that official European discourse on education has largely acquiesced in this abandonment of a universal for a sectional orientation, whether consciously or not. To many this latter may sound an alarming suggestion, or an unwarranted exaggeration, so to put it to the test it is worth looking in summary at 
the main features of a culture where the rational accommodation of diversity has yielded to the agonistic advance of disparity. These features have been described by Jean François Lyotard in his book The Postmodern Condition (Lyotard, 1984). Lyotard's book carries the subtitle A Report on Knowledge and his analysis seeks to document some of the more significant developments in outlook and action in the world of learning, and in cultural life more generally, in advanced technological societies of the present day. The tendencies identified in The Postmodern Condition include:

(a) the displacement of criteria of justification by criteria of performance, or effectiveness;

(b) the superseding of long-term commitments by temporary contracts;

(c) the divorce of knowledge from the personal qualities nurtured by learning;

(d) the commercialisation of knowledge, as a specialist and powerrelated commodity;

(e) a disbelief in accounts of meaningful ends for humankind as a whole ('metanarratives'), and the substitution instead of a more individualist conception of human action as a disparate multiplicity of 'language games' where the participants manoeuvre for power through 'moves' in the game.

The first four of these characteristics are likely to be quite familiar to those acquainted with the main shifts of direction in official educational discourse and practice in most of the OECD countries in the last decade and a half. They are also recognisable in substantial degree in the provisions of Teaching and Learning: towards the Learning Society, with the possible exception of the objective of combating social exclusion. This objective is worthy of closer examination, as the manner of its appearance in the European White Paper throws a significant light on the moral purposes of the White Paper as a whole. On the face of it, its inspiration comes from egalitarian political convictions. But something else is also at work here. The White Paper expresses the conviction as follows in its Introduction, 'Everyone must be able to seize their opportunities for improvement in society and for personal fulfilment, irrespective of their social origin and educational background' (p. 17, emphasis in original). Already here there is a hint of something more calculating, based on an awareness that the event of large numbers of disaffected or marginalised people is dysfunctional for society as a whole, and costly to deal with in more ways than one. In this instance egalitarian political conviction is not abandoned, but it becomes subtly transformed by its fusion with something else.

The infusion of inspirations of this more calculating kind can be gleaned from many passages in the White Paper, of which the following, also taken from the Introduction, is a good example: 'The level of skill achieved by each and everyone will have to be converted into an instrument for measuring individual performance in a way which will 
guarantee equal rights for workers as far as possible' (p. 17, emphasis in original). The altruistic note in both extracts from the White Paper, like that of other passages in the Paper where an altruistic note appears, is nevertheless cast in a language where the prevailing voice is that of individualism. More precisely, it is a language which attempts to canvass commitments and mobilise energies on behalf of a new cluster of beliefs - a competitive individualism fuelled on the one hand by economic and technological imperatives and restrained on the other by inherited legal frameworks and by the necessity for urbanity in a public arena made more public still by the unceasing attentions of national and international news media. ${ }^{8}$ A strictly Lyotardian reading of this concern for rights would read as follows: 'Rights do not flow from hardship, but from the fact that an alleviation of hardship improves the system's performance' (Lyotard, 1984, p. 63).

Apart from the objective of 'combating social exclusion', the other four objectives of the White Paper proceed more straightforwardly from an outlook which views the public sphere essentially as a social market and education largely as a service industry for that market: skilling pupils in the new knowledge needed for accelerated technological advance, bringing schools and business closer together, promoting communicative proficiency in three European languages, and treating capital investment and investment in training on an equal basis. These four objectives reveal something of the rationale behind the European Commission's dissolution of the distinction between education and training and betoken the Commission's preoccupation with the performance expectations of a market culture. The distinctive purposes of education as an undertaking in its own right are relegated, and the question of their justification becomes largely redundant. Pride of place is given instead to promoting excellences of a mercenary kind.

While the first four of the features I have listed above from Lyotard's characterisation of the postmodern condition can be seen to be active in educational thought and discourse at the most influential levels in Europe, it might be objected that the final feature in the five-point list - (e), above - does not apply here. It might be pointed out, for instance, that the disenchanted relativism it betrays does not seem to have featured prominently in the waves of educational reform in many Western countries since the early 1980s. But when placed under scrutiny this conclusion can be seen to mask something much more important than what it expresses. The market ideology that was the inspiration of much of this reform could win the day in the field of education only where a more substantive vision had lost its influence or had somehow become mute amid a throng of competing outlooks. ${ }^{9}$ Yet what is at issue here in the first instance is not so much the actual loss of belief in an educational vision, as a self-defeating reticence to articulate the belief. That is to say that reticence, the failure to articulate afresh a vision of moral purpose in response to new challenges, contributes to a waning of belief itself. In the case we are considering, this waning not only makes way for scepticism, relativism, or incredulity towards moral traditions 
which is evident in the last of the five features of the postmodern which I have drawn from Lyotard's account. It also provides the context in which the other four features become properly coherent. When requirements for justification in rational or doctrinal terms and questions of decisive moral import become supplanted by the criterion of performativity, then preoccupation with the ever-changing imperatives of effectiveness in performance beclouds or smothers convictions and loyalties of a more enduring kind - ones which seek to make a qualitative difference to the lives of learners in the longer term.

To the extent that virtue-bearing traditions of learning have become effectively eclipsed by the features of a postmodern culture as described by Lyotard, it no longer makes sense for education to voice claims for discretionary freedom, or for autonomy of professional practice; unless of course such freedom and autonomy are understood as the scope to produce higher standards of performance which can be readily measured by a 'value added' calculation of inputs and outputs. To that extent, moreover, education becomes important chiefly as a sub-system of a larger socioeconomic system, with supra-national as well as national goals. Thus within this larger socioeconomic frame pluralistic influences are to be tolerated, but also contained. ${ }^{10}$

The conclusions I have expressed here are ones of degree, as the repeated use of the phrase 'to the extent that' indicates. People may differ in their assessments of the strength of the tendencies I have been exploring, and I myself do not take a strictly Lyotardian view of these tendencies. But it is difficult to see how anyone seriously concerned with the educational realities of Western democracies in our own day can be credible in ignoring them or justified in disregarding them. On the other hand, if these tendencies were all-determining, there would be little point in arguing the case that the remainder of this essay is concerned with, because there would be no forum where such a case could make any difference.

In brief, there is an important lesson to be learnt from this exploration of wild pluralism and its consequences. Where an emergent cluster of sectional attitudes and practices attains an unacknowledged dominance in a culture which is largely thought to be pluralist in a democratic sense, then it is crucial that the tenor and scope of that dominance be made explicit and interrogated. To fail to do so is to allow the emergent attitudes and practices to become a new orthodoxy by default and to acquiesce in the unchallenged play of their influences in the various fields of public life. This lesson provides a good starting-point for a more positive appraisal of the heritage of European learning than the appraisals of that heritage reviewed in this section of the essay.

\section{TEACHING AND LEARNING AS A VIRTUE-BEARING PRACTICE}

A virtue-bearing tradition, say in religion, education or in cultural upbringing more generally, may also carry with it unacknowledged vices. These can include distorted or deprecatory perceptions of other traditions, discriminatory or otherwise exclusionary practices, authoritarian or 
permissive patterns in relations between teachers and learners, internal acrimonies concerning matters of belief and conduct. Even a cultural heritage which seeks to be understood in the most inclusive and critically alert manner, including the heritage of European learning which from classical times onwards has gone by the name of paideia, or humanitas, can with some justification be criticised as privileging certain insights and intellectual preferences. (Consider for instance the objection that this heritage privileges the preferences of 'dead white males'.) Such partiality should provide reason however neither for hasty dismissal of a particular tradition, nor for its uncritical embrace. To make available a heritage of learning from which all strategic distortions, institutionalised biases and smothered prejudices have been removed, is a task burdened with intractable difficulties. This goes some way towards explaining (though not justifying) the attitude of 'incredulity towards metanarratives' which Lyotard takes to be the chief mark of what he calls the postmodern condition.

In a critical sense, postmodernist standpoints can teach some sobering and salutary lessons. But when one asks more positively what it is for the sake of which critiques (such as Lyotard's, or indeed Foucault's) are carried out, there is little of a practical character, to say nothing of a defensible character, forthcoming from the ever-widening range of thinking which locates itself in the wake of modernity. Where suspicion and scepticism become the cardinal virtues, as they do in the writings of most of the postmodernists who have followed Nietzsche, wild pluralism follows as the most likely consequence for those who express these negative virtues in their thinking, utterances and actions. And it is difficult to see how much of practical educational promise can be gleaned where reciprocal acrimonies become characteristic of cultures of learning themselves. Meanwhile, on the wider stage, though partly hidden by the turbulence of wild pluralism, a creed with a new uniformity continues to insinuate itself and, with well-meaning and well-resourced commending from official quarters, to extend its roots into popular culture.

Postmodernist standpoints warn that every engagement with traditions of learning which is conceived in positive terms is inescapably laden with invidious distinctions, manipulative practices, or the undisclosed exercise of violence. ${ }^{11}$ Characterisations like those of Marrou and Maritain mentioned at the outset are thus obvious targets for postmodernist critique, but so also are characterisations in the tradition of Rousseau, or ones born of his or of Marxist or other emancipatory intent. Thus the postmodernist predilection for the negative side of critique can quickly lead to an endless quarantining, or an effective silencing, of some of the most distinctive voices in European traditions of learning. When viewed from a practical standpoint, this would leave teaching and learning largely in a bereft or debilitated state. To remedy this with a techno-economic faith in a new European future is to mask a void with busy, even frenetic, activity.

But the awareness that our understanding can never be free of inbuilt prejudices is not something which should give reason for indecision, or 
paralysis, or embarrassment, or defeatist acquiescence in the designs of commercial-cum-political interests. More properly, it should be regarded as a source of both inspiration and proper humility in educational efforts. This is something Socrates of Athens seems to have perceptively understood over two thousand years ago, but something which western learning has largely forgotten since. ${ }^{12}$ If the 'prejudice' issue we are faced with here is an inescapable feature of human understanding itself, as researches from a diversity of sources in the western traditions of philosophy have in recent times pointed out, ${ }^{13}$ then we have before us an insight with implications of central importance to how the enterprise of teaching and learning might best be conceived, conducted and defended. Rather than be swept under the carpet or otherwise disowned, this insight and its implications need to be explored, shared and worked into practice. The research literature I have just mentioned is much too large to review in detail, yet a summary of some of its main points may disclose something of the promise it holds for how educational efforts are to be understood and carried out in the wake of modernity's shaken faith in unshakeable foundations.

All human efforts to understand are inescapably coloured by previous experience and are thus constrained by perspective. So each of us - as human beings - will always understand incompletely, and in some degree differently. Far from something that can be eliminated by careful method, interpretation is a built-in characteristic of understanding itself. In each case then, our understanding is constituted by a partiality, in the sense both of bias and incompleteness: a partiality which cannot be finally overcome during our lifetimes. Far from our being forced to a despairing conclusion, however, there is an educational insight of first importance here. It is crucial to realise that we need not just be prisoners, or helpless victims, of this partiality. Our understanding can, through disciplined, co-operative and sustained efforts in any field of study, become more complete, even if it can never reach certainty or absolute knowledge. This applies to our dealings with scientific advances just as it does to our understanding of influential inherited conceptions such as humanitas. On the other hand, if the educational insight I am calling attention to is bypassed, or if its significance is misunderstood, as for instance in will-to-power theories from Nietzsche onwards, then the partiality inherent in understanding itself can quickly become more divisive and problematic. This can happen through overt or unnoticed practices in schooling as elsewhere: through ethnocentrism, sexism, narcissism, or any other discriminatory practices through which identity becomes primarily associated with the possession and exercise of power.

To act in judicious ways on an awareness of the inherent features of understanding itself requires a commitment to certain practices rather than others: practices which recognise that teaching and learning become vulnerable to disfigurement of an intractable kind if their conduct becomes the preserve or prerogative of a particular group's outlook to the exclusion of others, be this the outlook of a particular religion, party, ethnic grouping, academic tradition, or whatever. To 
realise the best in ourselves as human learners is therefore to appreciate that we are a dialogue: a dialogue whose possibilities can be taken up ever anew, or on the other hand declined, or bypassed, or indeed systematically smothered. But this also means that dialogue is itself an alert, self-critical and demanding discipline where the practices of teaching and learning are concerned. The distinctiveness of educational practice is therefore to be found just as much in the how of its conduct as in the what of its content. This implies a curriculum which is provided and experienced in such a way that it enables pupils and students to discover through their studies the strengths and the limitations that are unique to each of them. (And potentials for a range of technological and commercial occupations are likely to be more plentiful than scarce in this connection.) It is to acknowledge that the issue of personal identity is more a matter of epiphany than of imposition, of disclosure than of conformity, and to act on this acknowledgement with sincerity and professional perseverance. This in turn involves building an ethos, where a commitment to learning goes hand in hand with a sense of belonging to a community: one which undoubtedly has its own local flavour, yet where differences and tensions are not only acknowledged, but also experienced in such a way that they enlarge the context of what is taught and learned, enrich an appreciation of diversity and progressively discipline the preconceptions that underlie the exercise of all judgement.

The professional insights and qualities required to become accomplished in practices of the kind mentioned here define teaching as a practice to which a particular range of virtues applies. ${ }^{14}$ The virtues in question all find their natural exercise in what I have called above the discipline of dialogue. As distinct from wild pluralism, or the politics of power and enmity associated with it, this discipline is constituted by qualities such as the following:

(1) A readiness to listen to what the other party has to say, including that party's strongest criticisms of one's own standpoint;

(2) a readiness to grant that there may be distinctive insights and points of merit in the perspectives of the other party;

(3) an ability to discern and a willingness to note the most significant points in the other party's perspectives, including any points of agreement with one's own standpoint, any points of difference, and any areas of new ground;

(4) the capacity to bring one's own standpoint incisively into play and to explore in a self-critical way the merits of the various perspectives which have been offered by the different parties;

(5) a willingness to put the claim to truth in one's own perspective at risk, in the effort to achieve a more inclusive understanding, a revised and possibly a transformed one.

It might be argued that something of this discipline must be present if negotiations of any kind whatsoever are to be successful, and I have no wish to deny this. More pertinently, however, it must be pointed out that 
educational practices will become seriously disfigured unless a discipline of this kind is substantially present in the professional work of teachers. And this conclusion, which arises from what we have explored of the inescapable characteristics of human understanding itself, distinguishes the office of education from other engagements of public life, where the exercise of influence is rarely divorced from strategic considerations of power. To acknowledge this is to recognise the following as requirements of policy and procedure: that education has its own integrity as a distinct practice, or range of practices; that it is entitled to a measure of sovereignty in the discharge of its office; that the state of health of a country's culture, economy and politics depends quite heavily on the extent to which these requirements are honoured in practice. If they are not honoured in a self-conscious way in schools and colleges, it is difficult to see how they will bear any fruit elsewhere.

\section{CONCLUSION}

Michael Oakeshott's essays on education include some of the most eloquent arguments in print for respecting teaching and learning as a practice with an integrity and traditions of its own. Oakeshott writes of an engagement through which learners are 'emancipated from the modishness of merely current opinions', where they are 'initiated into the mysteries of a human condition', where an inheritance worthy of the learner's efforts is encountered in such a manner that it yields 'the gift of self-knowledge and of a satisfying intellectual and moral identity' 15 (Oakeshott, 1972, pp.69-70). He describes the teacher not as an agent of state, church or commercial interests, but as 'one in whom some part or aspect or passage of this inheritance is alive' and in such a way that it is capable of calling forth sincere, sustained and restrained responses from pupils. Not surprisingly, he insists that the school must be considered 'a place apart' from the concerns of politics and business, a place where learners may encounter 'an estate, entire, unqualified and unencumbered' (Oakeshott, 1972, p. 69). The claims to sovereignty on the part of the educational enterprise are clearly in evidence here and the contrast with both postmodernist scepticism and the new individualism of European educational policy could scarcely be more pronounced.

It is of course possible to criticise arguments like Oakeshott's as those of a conservative who defends the cause of an elitist concept of liberal education, with its built-in inequities, conceits, distortions and so on. Thus a familiar terrain for critique opens up again, with abundant possibilities for de-constructive moves and for judgements that can plausibly be sustained. And in this effort something vital also gets left out of account.

But what if the arguments for considering school as place apart are sundered from Oakeshott's avowed conservatism and rethought on a different basis? Then quite a different vista opens up. If they are linked systematically to those features of human understanding that I have here argued are inescapable ones, the arguments about education having an 
integrity of its own lose the partisan character which the label 'conservative' might attribute to them. By the same token, and much more significantly, they now become robust candidates for universal acceptance by anyone who has a serious concern with teaching and learning. The use of the word 'candidates' here is deliberate, as it eschews both absolutism and certainty and is in keeping with the selfcritical emphasis and the openness to refutation which we examined earlier when exploring the educational import of the discipline of dialogue.

A European educational policy built on arguments of this kind would be different in major respects from the White Paper Teaching and Learning: Towards the Learning Society. It is something to be encouraged and would indeed be something to be welcomed.

\section{Correspondence: Pádraig Hogan, Department of Education, National University of Ireland Maynooth, Maynooth, Co. Kildare, Ireland.}

\section{NOTES}

1. For a recent review of the merits and shortcomings of market approaches to public education, undertaken from a range of perspectives, see Bridges and McLaughlin (1994).

2. Not until the twentieth century did the ideas of authors like Dewey, Pestalozzi and Froebel find a significant place in the mainstream of educational thinking and practice, bringing with them strong claims for much more professional discretion and freedom for teachers.

3. This is asserted in two different passages on p. 42 of the White Paper, Teaching and Learning: Towards the Learning Society. Neither passage pays any attention to ample evidence of contrary trends internationally. The passages are as follows: 'Everyone is convinced of the need for change, the proof being the demise of the major ideological disputes on the objectives of education'. And a little further down the page, under a heading which reads 'The end of debate on educational principles', the White Paper declares as follows: 'Heated debates concerning the organisation of education and training systems - including debates on content and training methods - have taken place over the last few years. Most of these debates now appear to have come to an end'.

4. Part Two of the White Paper is devoted to setting out and supporting these objectives (pp. 49-74).

5. Alasdair MacIntyre argues strongly in support of the new Dark Age thesis, not only in relation to education, but also in relation to the entire moral discourse of Western civilisations. Different aspects of this thesis are emphasised in MacIntyre's writings since the early 1980s: After Virtue (1981), Whose Justice? Which Rationality? (1988); Three Rival Versions of Moral Enquiry (1990). See also his essay 'The idea of an educated public' in Graham Haydon (ed.), Education and Values (London: University of London Institute of Education, 1987). MacIntyre's is far from a lone voice. In his controversial book The Western Canon (London: Macmillan, 1995), Harold Bloom opens with an 'elegy for the canon' and argues vehemently against what he sees as a recent and relentless invasion of higher learning by political and social purposes. From a somewhat different perspective, Allan Bloom's The Closing of the American Mind (New York: Simon \& Schuster, 1987) also bemoans what its author views as the chaos and decay which has taken hold of American higher education.

6. The key difference here is that between putting up with the requirements of pluralism on the one hand and actively practising and promoting pluralism as a civic virtue on the other, e.g. listening with an open mind to standpoints which contrast with or challenge one's own, being disposed to acknowledge merits, even strong merits in such standpoints, being prepared to work democratic procedures to accommodate rather than to marginalise such standpoints. 
7. This five-point summary is drawn mainly from my own review of Lyotard's work in The Custody and Courtship of Experience: Western Education in Philosophical Perspective (Dublin: The Columba Press, 1995), pp. 109-113. In that review I have set out a seven-point summary of Lyotard's position.

8. I am not suggesting that the beliefs themselves are new, but rather that their clustering is, as is evident in the European White Paper, Teaching and Learning: Towards the Learning Society. Unlike traditional utilitarianism, which invoked slogans like 'the greatest happiness of the greatest number', the morality of the new faith I am seeking to describe springs from the threefold imperative of technological innovation, economic success and individual enterprise. So its slogan would be something like 'the greatest performance of the greatest number'.

9. Charles Taylor has some perceptive observations to make on the debilitation of moral energies and the hesitancy of moral convictions in the modern West in his book Sources of the Self: The Making of the Modern Identity (Cambridge: Cambridge University Press, 1989), especially chapter 3, 'Ethics of inarticulacy'. He revisits some of these observations in a more recent short book, The Ethics of Authenticity (Cambridge, MA: Harvard University Press), chapter 2 'The inarticulate debate'.

10. The tendency towards conformity, and indeed uniformity, in this larger scheme of things is evident in the following remarkable passage from the European Commission's White Paper. 'To examine education and training in the context of employment does not mean reducing them simply to a mean of obtaining qualifications. The essential aim of education and training has always been personal development and the successful integration of Europeans into society through the sharing of common values, the passing of cultural heritage and the teaching of selfreliance' (p. 18). The passage obscures the distinctiveness and denies the diversity of most that is of abiding worth in the heritage of European civilisations, while at the same time attempting to press this heritage itself into service in advancing a new educational orthodoxy for Europe. The White Paper fails to acknowledge even in a minimal way the politics of identity, of recognition, and of difference, which are central to what its own argument invokes as Europe's 'cultural wealth and diversity' (p.17 and passim). The fact that it shows no awareness of the vast contemporary literature on these issues reveals the superficiality of the invocation and also something of its tendentious character.

11. Recent articles in this and other journals have considered the formidable challenges to education as a public undertaking which arise from postmodernist standpoints. Among these articles are M. Peters (1995); P. Smeyers (1995a,b); P. Standish (1995); W. Carr (1997); N. Blake $(1996,1997)$. Each of these articles contributes, in different ways, to an alert awareness of the difficulties which arise for coherent, defensible action in education in the circumstances of late modernity, i.e. in the wake of the many exclusionary outlooks and practices which Enlightenment rationalisms have visited on the pursuit of learning and the conduct of teaching. In the spirit of much postmodernist critique, some of these articles remain sceptical of any orientation which might seek to defend educational efforts in universal terms. Others, conscious of the point that education is a practice more than a theoretical undertaking, seek to navigate some pathways through the difficulties. My own efforts also lie in this latter direction, but in a way which attempts to reclaim universality by breaking with the epistemological currents of the Enlightenment heritage. Finally, although not explicitly a work on educational practice, Feminisms and the Self, by Morwenna Griffiths (1995), has many original and convincing insights to offer which bear directly on navigating the difficulties just mentioned.

12. This eclipse of the Socratic is one of the central themes I have explored in The Custody and Courtship of Experience: Western Education in Philosophical Perspective (Hogan, 1995).

13. The findings of this research deal a hammer blow to traditional epistemology and its quest for unshakeable certainty. The findings are best summed up in Hans-Georg Gadamer's formulation 'It is not so much our judgements as it is our prejudices that constitute our being' (Philosophical Hermeneutics, 1977, p. 9). Gadamer makes a central research theme of 'Heidegger's disclosure of the fore-structure of understanding' in his own major work Truth and Method (1975) and regularly acknowledges his debt to Heidegger. So also do Paul Ricoeur (1981) and other thinkers associated with hermeneutic philosophy. But insights of a related kind are also evident in the work of Karl Popper (1979), the later work of Wittgenstein (1978), some currents in American pragmatism, and most recently, the work of philosophers Richard J. Bernstein (1991), Seyla Benhabib (1991) and Charles Taylor (1995). 
14. I have attempted to list this range of virtues and to explore in some detail their embodiment in practice in The Custody and Courtship of Experience, pp. 168-176.

15. Oakeshott makes points of this kind in a number of his essays, but most notably in his 1972 essay 'Education: the engagement and its frustration', reprinted in T. Fuller (ed.) (1989), The Voice of Liberal Learning: Michael Oakeshott on Education. In this connection I also want to draw attention to two other recent writings which get behind the 'conservative' label generally attached to Oakeshott and which highlight the originality, subtlety and promise of different aspects of his educational arguments. These writings are Kevin Williams (1996) and Paul Smeyers (1995b).

\section{REFERENCES}

Benhabib, Seyla (1992) Situating the Self: gender, community and postmodernism in contemporary ethics (Cambridge: Polity Press/Basil Blackwell).

Bernstein, Richard J. (1987) Varieties of pluralism, American Journal of Education, 95. 4.

Bernstein, Richard J. (1991) The New Constellation: The Ethical-Political Horizons of Modernity/ Postmodernity (Cambridge: Polity Press/Basil Blackwell).

Blake, Nigel (1996) Between postmodernism and antimodernism: the predicament of educational studies, British Journal of Educational Studies, 44. 1, pp. 42-65.

Blake, Nigel (1997) A postmodernism worth bothering about: a rejoinder to Cole, Hill and Rikowski, British Journal of Educational Studies, 45. 3, pp. 293-305.

Bloom, Allan (1987) The Closing of the American Mind (New York: Simon \& Schuster).

Bloom, Harold (1995) The Western Canon (London: Macmillan).

Bridges, D. and McLaughlin, T. H. (eds) (1994) Education and the Market Place (London: Falmer).

Carr, Wilfred (1997) Professing education in a postmodern age, Journal of Philosophy of Education, 31. 2, pp. 309-327.

European Commission, Directorates General XXII \& V (1996) Teaching and Learning: Towards the Learning Society, a White Paper on education and training (Luxembourg, Office for Official Publications of the European Communities). The text of this White Paper is also available on the Internet at http://www.cec.lu/en/comm/dg22.html.

Fukuyama, Francis (1992) The End of History and the Last Man (London: Hamish Hamilton).

Gadamer, Hans-Georg (1975) Truth and Method, trans. G. Barden and J. Cumming (London: Sheed \& Ward. Originally published in German in 1960).

Gadamer, Hans-Georg (1977) Philosophical Hermeneutics, trans. and ed. David E. Linge (Berkeley: University of California Press).

Griffiths, Morwenna (1995) Feminisms and the Self: The Web of Identity (London: Routledge).

Haydon, G. (ed.) (1987) Education and Values (London: University of London Institute of Education).

Hogan, Pádraig (1995) The Custody and Courtship of Experience: Western Education in Philosophical Perspective (Dublin: The Columba Press).

Lyotard, Jean François (1984) The Postmodern Condition: A Report on Knowledge, trans. G. Bennington and B. Massumi (Manchester: Manchester University Press. Originally published in French in 1979).

MacIntyre, Alasdair (1985) After Virtue: a study in moral theory (London: Duckworth).

MacIntyre, Alasdair (1988) Whose Justice? Which Rationality? (London: Duckworth).

MacIntyre, Alasdair (1988) Three Rival Versions of Moral Enquiry (London: Duckworth).

Maritain, Jacques (1960) Education at the Crossroads (New Haven: Yale University Press. Originally published in 1943).

Marrou, Henri (1956) A History of Education in Antiquity, trans. George Lamb (New York: Sheed \& Ward).

Oakeshott, Michael (1972) Education: the engagement and its frustration, in: Fuller, T. (ed.) (1989) The Voice of Liberal Learning: Michael Oakeshott on Education (New Haven: Yale University Press).

Peters, Michael (1995) Education and the postmodern condition: re-visiting Jean François Lyotard, Journal of Philosophy of Education, 29.3, pp. 387-400.

Popper, Karl (1979) Objective Knowledge: An Evolutionary Approach (Oxford: Clarendon Press). 


\section{Pádraig Hogan}

Ricoeur, Paul (1981) Hermeneutics and the Human Sciences: Essays on language, action and interpretation, trans. John B. Thompson (Cambridge: Cambridge University Press).

Smeyers, Paul (1995a) Education and the educational project I: the atmosphere of post-modernism, Journal of Philosophy of Education, 29. 1, pp. 109-119.

Smeyers, Paul (1995b) Education and the educational project II: do we still care about it? Journal of Philosophy of Education, 29. 3, pp. 401-413.

Standish, Paul (1995) Postmodernism and the education of the whole person, Journal of Philosophy of Education, 29.1, pp. 121-135.

Taylor, Charles (1989) Sources of the Self: The Making of the Modern Identity (Cambridge: Cambridge University Press, 1989).

Taylor, Charles (1991) The Ethics of Authenticity (Cambridge, Mass.: Harvard University Press).

Taylor, Charles (1995) Philosophical Arguments (Cambridge, Mass.: Harvard University Press).

Williams, Kevin (1996) The discipline of inclination: Michael Oakeshott's treatment of the issue of compulsion in the teacher-pupil relationship, Westminster Studies in Education, 19. 1, pp. 15-23.

Wittgenstein, Ludwig (1978) Philosophical Investigations, trans. G.E.M. Anscombe (Oxford: Basil Blackwell). 